\title{
Erratum
}

\section{Neuropsychological deficits in human immunodeficiency virus type 1 clade C-seropositive adults from South India}

\author{
Jayashree Das Gupta, ${ }^{1}$ Shobini Rao, ${ }^{1}$ P Satishchandra, ${ }^{2}$ Kumarpillai Gopukumar, ${ }^{1}$ Frances Wilkie, ${ }^{3}$ \\ Drenna Waldrop-Valverde, ${ }^{3}$ Ronald Ellis, ${ }^{4}$ Raymond Ownby, ${ }^{3}$ D K Subbakrishna, ${ }^{5}$ Anita Desai, ${ }^{6}$ \\ Anupa Kamat, ${ }^{6}$ V Ravi, ${ }^{6}$ B S Rao, ${ }^{7}$ K S Satish, ${ }^{7}$ and Mahendra Kumar $^{3}$ \\ Departments of ${ }^{1}$ Mental Health \& Social Psychology, ${ }^{2}$ Neurology, ${ }^{5}$ Biostatistics and ${ }^{6}$ Neurovirology, National Institute \\ of Mental Health \& Neuro Sciences, Bangalore, Karnataka, India \\ ${ }^{3}$ Department of Psychiatry and Behavioral Sciences, University of Miami School of Medicine, Florida, USA \\ ${ }^{4}$ HIV Neurobehavioral Research Center, University of California, San Diego, La Jolla, California, USA \\ ${ }^{7}$ Seva Free Clinic, Bangalore, Karnataka, India
}

\begin{abstract}
Most studies of cognitive functioning in human immunodeficiency virus type 1 (HIV-1)-seropositive (HIV-1+) subjects have been done in the United States and Europe, where clade $B$ infections predominate. However, in other parts of the world such as South India, where clade C HIV is most common, the prevalence of HIV-1 is increasing. Standardized neuropsychological tests were used to assess cognitive functioning in a sample of 119 adults infected with clade C HIV-1 who were not on antiretroviral medications. The subjects did not have neurological or psychiatric illness and were functioning adequately. Neuropsychological test performance was compared with gender-, age-, and education-matched normative data derived from a sample of 540 healthy volunteers and a matched cohort of 126 healthy, HIV-1-seronegative individuals. Among the seropositive subjects, $60.5 \%$ had mild to moderate cognitive deficits characterized by deficits in the domains of fluency, working memory, and learning and memory. None of the subjects had severe cognitive deficits. The HIV-1 + sample was classified into groups according to the level of immune suppression as defined by CD4 count $\left(<200,201-499\right.$, and $\left.>500 \mathrm{cells} / \mathrm{mm}^{3}\right)$ and viral load $(<5000,5001-30,000,30,001-99,999,100,000-1,000,000$, and $>1,000,001$ copies). Although the most immunosuppressed group (CD4 count $<200$ cells $/ \mathrm{mm}^{3}$ or viral load $>1,000,001$ copies) was small, their rate of impairment in visual working memory was greater when compared to groups with better immune functioning. Mild to moderate cognitive deficits can be identified on standardized neuropsychological tests in clade C-infected HIV-1+ adults who do not have any clinically identifiable functional impairment. The prevalence of cognitive deficits is similar to that reported in antiretroviral treatment-naïve individuals infected with clade $B$ virus in the western world. Journal of NeuroVirology (2007) 13, 397-398.
\end{abstract}

Keywords: clade C; cognition; HIV; neuropsychology; working memory

Address correspondence to Prof. Shobini Rao, Department of Mental Health \& Social Psychology, National Institute of Mental Health \& Neuro Sciences, Bangalore 560029, Karnataka, India. E-mail: shobini@nimhans.kar.nic.in

This study has been supported by grant R01 NS 41205 from NIH, USA, and approved by ICMR, New Delhi.

Received 27 October 2006; revised 18 December 2006; accepted 24 January 2007. 
Table 1 Comparison of deficits in HIV+ subjects with seronegative controls and difference in cognitive functioning across immune suppression groups

\begin{tabular}{|c|c|c|c|c|c|c|}
\hline & & & $\begin{array}{l}\text { Differences across } \\
\text { CD4 count groups }\end{array}$ & & $\begin{array}{l}\text { Differences across plasma } \\
\text { viral load groups }\end{array}$ & \\
\hline Test variable & $\begin{array}{l}\mathrm{X}^{2} \text { (Based on number } \\
\text { of deficits in HIV+ } \\
\text { and HIV-groups) df }=1\end{array}$ & $\begin{array}{l}\text { Level of } \\
\text { significance }\end{array}$ & $\begin{array}{c}\text { ANCOVA } \\
\text { (Based on raw test scores) } \\
\text { F ratio }(\mathrm{df}=2)\end{array}$ & $\begin{array}{l}\text { Level of } \\
\text { significance }\end{array}$ & $\begin{array}{c}\text { ANOVA } \\
\text { (Based on raw test scores) } \\
\text { F ratio }(\mathrm{df}=4)\end{array}$ & $\begin{array}{l}\text { Level of } \\
\text { significance }\end{array}$ \\
\hline FT LH & 2.10 & 0.15 & 0.08 & 0.92 & 0.38 & 0.83 \\
\hline FT RH & 3.59 & 0.06 & 0.29 & 0.75 & 0.44 & 0.78 \\
\hline $\mathrm{AF}$ & 0.69 & 0.40 & 0.86 & 0.43 & 0.17 & 0.95 \\
\hline $\mathrm{PF}$ & 6.44 & 0.01 & 1.82 & 0.83 & 1.23 & 0.30 \\
\hline VM 1 & 0.14 & 0.71 & 0.67 & 0.52 & 1.22 & 0.31 \\
\hline VM 2 & 9.18 & 0.00 & 0.00 & 0.99 & 0.07 & 0.99 \\
\hline VIM 1 & 0.13 & 0.72 & 0.60 & 0.55 & 3.06 & 0.02 \\
\hline VIM 2 & 0.25 & 0.62 & 4.31 & 0.01 & 1.92 & 0.11 \\
\hline AVLTI-V Total & 11.39 & 0.00 & 0.62 & 0.54 & 0.66 & 0.62 \\
\hline AVLT IR & 7.33 & 0.00 & 1.06 & 0.35 & 0.55 & 0.70 \\
\hline AVLT DR & 6.97 & 0.00 & 0.39 & 0.68 & 0.34 & 0.85 \\
\hline TNPMM & 0.00 & 0.95 & 0.85 & 0.43 & 0.68 & 0.61 \\
\hline
\end{tabular}

Note: PF = Phonemic Fluency, AF = Animal Fluency, FT LH = Finger Tapping Left Hand, FT RH = Finger Tapping Right Hand, VM1 = Verbal Working Memory 1-back hits, VM2 = Verbal Working Memory 2-back hits, VIM1 = Visual Working Memory 1-back hits, VIM2 = Visual Working Memory 2-back hits, TNPMM = Total number problems solved with minimum moves on Tower of London Test, AVLT $=$ Auditory Verbal Learing Test, IR = Immediate Recall, DR = Delayed Recall. 